\title{
WIDEBAND IMMITTANCE IN NEONATES: A SYSTEMATIC LITERATURE REVIEW
}

\author{
Thais Antonelli Diniz Hein, Milaine Dominici Sanfins \\ Faculty of Medical Science, University of Campinas (Unicamp), Campinas, São Paulo, SP, Brazil
}

Corresponding author: Thais Antonelli Diniz Hein, Faculty of Medical Science, State University of Campinas, Rua Tessalia Vieira de Camargo, 126 Cidade Universitária Zeferino Vaz, CEP 13083-887, Campinas, SP, Brazil, e-mail: thaisdiniz@uol.com.br

\begin{abstract}
Objective: To analyze the literature on wideband immittance testing and to evaluate the success of these procedures in evaluating middle ear function in newborns.

Methods: A systematic literature review was conducted using as keywords: wideband, tympanometry, reflectance, absorbance, immittance. Papers which did not address neonates were excluded from the review. From each article specific information was extracted referring to the following: sample size, population characteristics, equipment, stimulus type, study evaluation, and study conclusion.
\end{abstract}

Conclusions: This systematic review considers that wideband immittance is a promising way for evaluating middle ear function in neonates. It is necessary to establish regulatory standards for different age groups of neonates and infants.

Key words: infants $\bullet$ middle ear $\bullet$ wideband absorbance $\bullet$ reflectance $\bullet$ tympanometry

\section{IMPEDANCIOMETRÍA DE BANDA ANCHA EN NEONATOS: UNA REVISIÓN BIBLIOGRÁFICA}

\section{Resumen}

Objetivo: Revisión bibliográfica de los estudios científicos relativos a la impedanciometría de banda ancha y evaluación de la eficacia de dicho método en el diagnóstico de las funciones del oído medio en bebés.

Métodos e instrumentos de investigación: Los temas principales de la presente revisión de trabajos científicos han sido: la timpanometría de banda ancha, la reflectancia, la absorbancia, la immitancia. En ella, se han contemplado tan solo las publicaciones relativas a los neonatos, y en concreto los datos relativos a: el tamaño de la muestra, las características de la población, las condiciones del equipo, el tipo del estímulo, la valoración del estudio y de las conclusiones del mismo.

Conclusiones: La presente revisión bibliográfica ha demostrado que la impedanciometría de banda ancha constituye un método prometedor en la evaluación de las funciones del oído medio en neonatos. Es imprescindible elaborar estándares normalizados de prueba para neonatos y bebés de diferentes categorías de edad.

Palabras clave: bebés • oído medio • absorbancia • reflectancia • timpanometría de banda ancha

\section{ШИРОКОПОЛОСНАЯ ИМПЕДАНСНАЯ АУДИОМЕТРИЯ У НОВОРОЖДЕННЫХ: ОБЗОР ЛИТЕРАТУРЫ}

\section{Изложение}

Цель: Анализ литературы предмета в области исследования широкополосной импедансной аудиометрии, а также оценка эффективности данного метода в диагностике функций среднего уха у новорождённых.

Исследовательские методы и инструменты: Основными темами настоящего обзора литературы были: широкополосная тимпанометрия, отражающая способность, экстинкция (поглощающая способность), иммитанс. В него были включены только публикации о новорождённых, касающиеся размера испытания, характеристики популяции, технической базы, типа импульса, оценки исследования и выводов, следующих из него. 
Выводы: Настоящий обзор литературы показал, что широкополосная импедансная аудиометрия является многообещающим методом оценки функций среднего уха у новорождённых. Необходимо разработать нормализированные стандарты исследования для новорождённых и грудных детей из разных возрастных групп.

Ключевые слова: грудные дети • среднее ухо • экстинкция • отражающая способность • широкополосная тимпанометрия

\section{SZEROKOPASMOWA AUDIOMETRIA IMPEDANCYJNA U NOWORODKÓW: PRZEGLĄD LITERATURY}

\section{Streszczenie}

Cel: Analiza literatury przedmiotu, dotyczącej badania szerokopasmowej audiometrii impedancyjnej, oraz ocena efektywności tej metody w diagnostyce funkcji ucha środkowego u noworodków.

Metody i narzędzia badawcze: Tematami przewodnimi niniejszego przeglądu literatury były: tympanometria szerokopasmowa, reflektancja, absorbancja, immitancja. Włączono do niego tylko dane z publikacji o noworodkach, dotyczące: wielkości próby, charakterystyki populacji, warunków sprzętowych, typu bodźca, oceny badań i wniosków z niego płynących.

Wnioski: Niniejszy przegląd literatury pokazał, iż szerokopasmowa audiometria impedancyjna jest obiecującą metodą oceny funkcji ucha środkowego u noworodków. Niezbędne jest wypracowanie znormalizowanych standardów badania dla noworodków i niemowląt $\mathrm{z}$ różnych grup wiekowych.

Słowa kluczowe: niemowlęta $\bullet$ ucho środkowe $\bullet$ absorbancja $\bullet$ reflektancja $\bullet$ tympanometria szerokopasmowa

\section{Introduction}

A basic prerequisite for the proper development of language is the integrity of the auditory system [1], and so there is a strong correlation between auditory and language skills. This interdependence between hearing and language means it is important to have an effective diagnostic program and to intervene early when hearing loss is detected. Newborn hearing screening is therefore crucial $[1,2]$.

In general, newborn hearing screening protocols are a combination of electroacoustic and electrophysiological procedures. In newborns without risk indicators for hearing loss, the option is usually to carry out transient otoacoustic emission (TEOAE) testing, while in neonates with risk indicators for hearing loss the usual choice is an automated auditory brainstem response (AABR) test $[3,4]$. Neonatal hearing screening is usually performed in two steps, a test and a retest, which aims to reduce possible technical problems and excessive 'refer' outcomes [5].

Outcomes in neonatal hearing screening programs will always include some false positives (i.e. normal hearing infants evaluated as hearing impaired). The majority of these cases involve conditions which impair the function of the middle ear, observed as an impedance anomaly $[5,6]$. In neonates, the space occupied by the mastoid and the middle ear is smaller, the tympanic membrane is thinner and more horizontal, and the external auditory canal is less rigid (with the likelihood of it collapsing more easily) $[7,8]$. Due to the possible presence of amniotic fluid in the middle ear or in the external auditory canal, temporary alterations of hearing are often observed $[8,9]$. These alterations increase the mass, stiffness, and resistance of the eardrumossicular system and consequently alter middle ear impedance and the efficiency of sound conduction.
One way to assess middle ear status and functionality is by impedance tympanometry. When tympanometry is performed in newborns, the standard $226 \mathrm{~Hz}$ probe tone becomes a less sensitive test for identifying middle ear disorders $[3,10]$. It is possible to overcome the limitations of the $226 \mathrm{~Hz}$ tone by performing tympanometry with a 1 $\mathrm{kHz}$ probe. This procedure, which has been recommended for infants younger than 4 months by the American Academy of Pediatrics Joint Committee on Infant Hearing [3], is considered more sensitive in identifying middle ear disorders $[7,11,12]$. Nevertheless, several studies have questioned the real effectiveness of $1 \mathrm{kHz}$ tympanometry in infants [13], so at present there is no consensus on a gold standard for infant middle ear diagnosis.

Middle ear wideband tympanometry immittance (WBT) has been developed as a potentially more accurate procedure for identifying middle ear disorders. It offers information on the functional status of the middle ear at test frequencies from 226 to $8000 \mathrm{~Hz}$ [14-17]. Specific terms are used in WBT to describe the reflectance or absorbance of the acoustic stimuli: acoustic reflectance is the stimulus power reflected by the tympanic membrane, while acoustic absorbance is the amount of energy absorbed by the middle ear $[18,19]$. Both measures are frequency-dependent. WBT has the potential to offer a better description of middle ear function, perhaps becoming the missing gold standard in the diagnosis of middle ear disorders.

Neonatal hearing screening is a key step in the audiological diagnosis of infants [1]. The use of reliable tests with reproducible results is extremely important. Evaluation by WBT seems to have an important role in hearing screening, and can provide accurate information about the functioning of the middle ear. The objective of this study was 


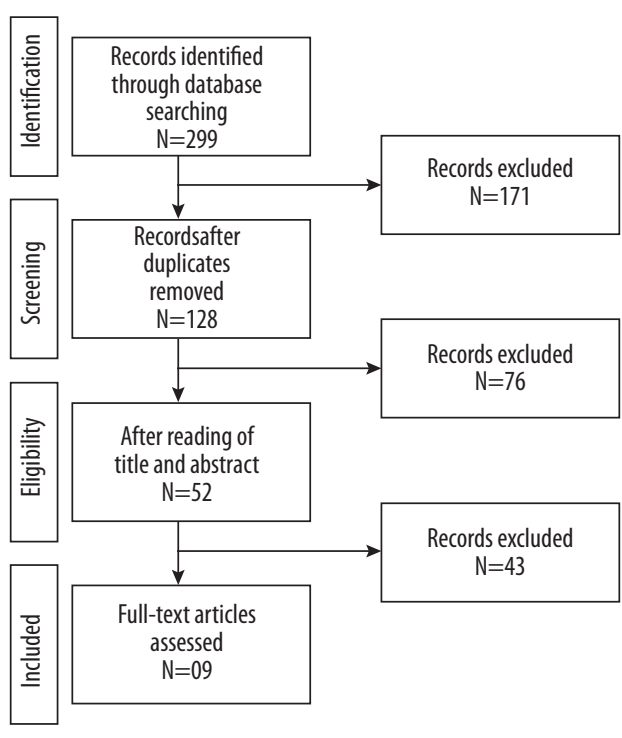

Figure 1. Flowchart of the article selection process

to evaluate information on WBT in the literature and assess how well the technique can be applied in the clinic to newborns.

\section{Methods}

This study was a systematic literature review on articles published in journals indexed in the following databases: US National Library of Medicine, National Institutes of Health (PubMed); Scientific Electronic Library Online (Scielo); Latin American and Caribbean Health Sciences (Lilacs); Elsevier's search engine tool (Scopus); and the ISI Web of Science. The descriptors were restricted to English, according to the following medical subject headlings $(\mathrm{MeSH})$ : wideband, tympanometry, reflectance, absorbance, and immittance. The study was conducted independently by the two authors and any disagreements were resolved through discussion. For the selection of suitable studies the following inclusion criteria were used.
1. Articles published within the last 10 years (2006-16). This specific time-frame was used because WBT technology was only introduced 10 years ago.

2. Original articles.

3. Articles based on samples of healthy babies, neonatal Intensive care unit (NICU) infants, or infants in general.

Exclusion criteria consisted of: 1) experiments on animals; 2) adult studies; 3 ) case studies; 4) literature review or editorials; 5) articles not published in English.

From each article, specific information was extracted on: sample size; population characteristics; equipment; stimulus type; study evaluation; and study conclusion.

\section{Results}

Searches of the electronic databases resulted in 299 studies. Excluded items occurred in three types: (a) duplicates, summaries including experimental animal or adults studies, unpublished articles in English or Portuguese and case study format or literature review $(n=128)$; (b) after reading title and abstract $(n=52)$; and (c) complete reading the article $(n=9)$. After this process, 9 articles were included for this review. A chart of the article selection process is shown in Figure 1. Table 1 (data on absorbance) and Table 2 (data on reflectance) show the data collected for each category.

\section{Discussion}

Since changes in middle ear function affect the conduction of sound to other parts of the auditory system, accurately evaluating the state of the middle ear is important for making reliable audiological diagnoses in neonates. Measuring immittance can be done using a number of procedures, including reflectance, absorbance, tympanometry, and the acoustic reflex.

In this systematic review, six studies assessed absorbance in neonates [13,20-24] using the Titan equipment (Interacoustics, Denmark). The remaining three [20-22] evaluated the reflectance in newborns through the MEPA equipment from Mimosa Acoustics.

Table 1. Description of absorbance related studies

\begin{tabular}{|c|c|c|c|c|c|c|c|}
\hline Article & No. & Sample & $\begin{array}{c}\text { Sample } \\
\text { characterization }\end{array}$ & Equipment & $\begin{array}{c}\text { Stimulus } \\
\text { type }\end{array}$ & Evaluation & Conclusion \\
\hline $\begin{array}{l}\text { Sanford } \\
\text { et al., } \\
2009\end{array}$ & 1 & $\begin{array}{l}455 \text { infant } \\
\text { ears }\end{array}$ & & $\begin{array}{l}\text { Reflwin } \\
\text { computerized } \\
\text { system and } \\
\text { controller } \\
\text { system } \\
\text { contained } \\
\text { in acoustic } \\
\text { immittance } \\
\text { instrument } \\
\text { (AT 235) }\end{array}$ & Click & $\begin{array}{l}\text { DPOAE } \\
\text { UNHS }\end{array}$ & $\begin{array}{l}\text { Results showed that: } 1 \text { ) WB tests } \\
\text { had better performance in classifying } \\
\text { UNHS DPOAE outcomes than } \\
\text { 1-kHz tympanometry; 2) WB tests } \\
\text { provide data suggesting that many } \\
\text { UNHS referrals are a consequence } \\
\text { of transient conditions affecting } \\
\text { the sound-conduction pathway; } 3 \text { ) } \\
\text { WB data reveal changes in sound } \\
\text { conduction during the first } 2 \text { days of } \\
\text { life; } 4 \text { ) WB measurements used in } \\
\text { the present study are objective and } \\
\text { quick, making these tests feasible } \\
\text { for potential use in conjunction with } \\
\text { UNHS programs }\end{array}$ \\
\hline
\end{tabular}


Table 1 continued. Description of absorbance related studies

\begin{tabular}{|c|c|c|c|c|c|c|c|}
\hline Article & No. & Sample & $\begin{array}{c}\text { Sample } \\
\text { characterization }\end{array}$ & Equipment & $\begin{array}{l}\text { Stimulus } \\
\text { type }\end{array}$ & Evaluation & Conclusion \\
\hline $\begin{array}{l}\text { Aithal } \\
\text { et al., } \\
2013\end{array}$ & 2 & 66 infants & $\begin{array}{l}\text { mean age }= \\
46.0 \mathrm{~h} \\
(\mathrm{SD} 21.0 ; \\
\text { range } \\
13.3-116.5 \mathrm{~h})\end{array}$ & $\begin{array}{l}\text { Reflwin } \\
\text { computerized } \\
\text { system and } \\
\text { controller } \\
\text { system } \\
\text { contained } \\
\text { in acoustic } \\
\text { immittance } \\
\text { instrument } \\
\text { (AT 235) }\end{array}$ & Click & $\begin{array}{l}\text { HFT } \\
\text { acoustic } \\
\text { stapedial } \\
\text { reflex } \\
\text { TEOAE } \\
\text { PDOAE }\end{array}$ & $\begin{array}{l}\text { The normative reflectance data in } \\
\text { the present study were in agreement } \\
\text { with, but marginally smaller than, } \\
\text { those of previous normative studies, } \\
\text { except for the study of Keefe et al. } \\
\text { (2000). Whereas the use of a test } \\
\text { battery approach to ensure normal } \\
\text { middle ear function in neonates } \\
\text { has resulted in slightly reduced } \\
\text { reflectance across most frequencies } \\
\text { (compared to studies that have used } \\
\text { only otoacoustic emissions), further } \\
\text { research is needed to accurately } \\
\text { determine the middle ear status of } \\
\text { neonates using test performance } \\
\text { measures }\end{array}$ \\
\hline $\begin{array}{l}\text { Aithal } \\
\text { et al., } \\
2014\end{array}$ & 3 & $\begin{array}{l}35 \text { newborns } \\
\text { (35 ears) } \\
16 \text { infants aged } \\
1 \text { mo ( } 29 \text { ears) } \\
16 \text { infants aged } \\
2 \text { mo ( } 29 \text { ears) } \\
15 \text { infants aged } \\
4 \text { mo ( } 28 \text { ears) } \\
14 \text { infants aged } \\
6 \text { mo ( } 27 \text { ears) }\end{array}$ & & $\begin{array}{l}\text { Reflwin } \\
\text { computerized } \\
\text { system and } \\
\text { controller } \\
\text { system } \\
\text { contained } \\
\text { in acoustic } \\
\text { immittance } \\
\text { instrument } \\
\text { (AT 235) }\end{array}$ & Click & $\begin{array}{l}\text { HFT } \\
\text { DPOAE }\end{array}$ & $\begin{array}{l}\text { Developmental effects of WBA were } \\
\text { evident for infants during the first } 6 \\
\text { mo of life. The WBA data can be used } \\
\text { as a reference for detecting disorders } \\
\text { in sound-conductive pathways (outer } \\
\text { and middle ear) in young infants. } \\
\text { Further development of age-specific } \\
\text { normative WBA data in young infants } \\
\text { is warranted }\end{array}$ \\
\hline $\begin{array}{l}\text { Aithal } \\
\text { et al., } \\
2014\end{array}$ & 4 & $\begin{array}{l}59 \text { ears: } 32 \\
\text { Aboriginal } \\
\text { neonates (AN); } \\
281 \text { ears: } 158 \\
\text { Caucasian } \\
\text { neonates (CN) }\end{array}$ & $\begin{array}{l}\text { AN: mean } \\
51.9 \mathrm{~h}(\mathrm{SD} \\
18.2 ; \text { range } \\
22-86 \mathrm{~h}) \\
\mathrm{CN}: \text { mean } \\
42.4 \mathrm{~h} \text { (SD } \\
23 \mathrm{~h} \text {; range } \\
8.1-152 \mathrm{~h})\end{array}$ & $\begin{array}{l}\text { Reflwin } \\
\text { computerized } \\
\text { system and } \\
\text { controller } \\
\text { system } \\
\text { contained } \\
\text { in acoustic } \\
\text { immittance } \\
\text { instrument } \\
\text { (AT 235) }\end{array}$ & Click & $\begin{array}{l}\text { HFT } \\
\text { DPOAE }\end{array}$ & $\begin{array}{l}\text { This study provided convincing } \\
\text { evidence that Aboriginal neonates } \\
\text { had significantly lower WBA values } \\
\text { than their Caucasian counterparts, } \\
\text { although both groups had equal } \\
\text { pass rates (as determined by the } \\
\text { test battery). Although the two } \\
\text { ethnic groups showed significant } \\
\text { differences in WBA, the factors } \\
\text { contributing to such differences } \\
\text { remain undetermined. Further } \\
\text { research is warranted to determine } \\
\text { the factors that might account for the } \\
\text { difference in WBA between the two } \\
\text { ethnic groups }\end{array}$ \\
\hline $\begin{array}{l}\text { Aithal } \\
\text { et al., } \\
2015\end{array}$ & 5 & $\begin{array}{l}192 \text { healthy } \\
\text { neonates } \\
\text { (108 males) }\end{array}$ & $\begin{array}{l}43.7 \mathrm{~h}(\mathrm{SD} \\
21.3, \text { range } \\
8.3-152.2 \mathrm{~h}) \\
\text { Mean } \\
\text { gestational } \\
\text { age of } \\
\text { neonates } 39.2 \\
\text { weeks (SD 1.2; } \\
\text { range 36-42 } \\
\text { weeks) } \\
\text { Mean birth } \\
\text { weight } \\
\text { 3476.9 g (SD } \\
460.9 ; \text { range } \\
2290-5000 \text { g) }\end{array}$ & $\begin{array}{l}\text { Reflwin } \\
\text { computerized } \\
\text { system and } \\
\text { controller } \\
\text { system } \\
\text { contained } \\
\text { in acoustic } \\
\text { immittance } \\
\text { instrument } \\
\text { (AT 235) }\end{array}$ & Click & $\begin{array}{l}\text { TEOAE, } \\
\text { DPOAE, } \\
\text { HFT } \\
\text { AABR }\end{array}$ & $\begin{array}{l}\text { The test performance of WBA against } \\
\text { test battery reference standards was } \\
\text { superior to that against single test } \\
\text { reference standards. } \\
\text { Valid test of conductive conditions, } \\
\text { WBA can be used in both screening } \\
\text { and diagnostic evaluations in } \\
\text { neonates. }\end{array}$ \\
\hline $\begin{array}{l}\text { Hunter } \\
\text { et al., } \\
2015\end{array}$ & 6 & $\begin{array}{l}182 \text { infants } \\
\text { who passed } \\
\text { hearing } \\
\text { screening ( } 54 \% \\
\text { males) }\end{array}$ & & Titan & Click & $\begin{array}{l}\text { NHS } \\
\text { TEOAE } \\
\text { AABR }\end{array}$ & $\begin{array}{l}\text { Separate normative references are } \\
\text { recommended for clinical application } \\
\text { for birth, } 1 \text { month, and } 6-15 \text { months. } \\
\text { These normative data are expected } \\
\text { to be useful in comparisons with } \\
\text { similar measurements in infant } \\
\text { ears with confirmed conductive and } \\
\text { sensorineural hearing loss. }\end{array}$ \\
\hline
\end{tabular}


Table 2. Description of reflectance related studies

\begin{tabular}{|c|c|c|c|c|c|c|c|}
\hline Article & No. & Sample & Sample characterization & Equipment & $\begin{array}{l}\text { Stimulus } \\
\text { type }\end{array}$ & Evaluation & Conclusion \\
\hline $\begin{array}{l}\text { Hunter } \\
\text { et al., } \\
2010\end{array}$ & 7 & $\begin{array}{l}\text { UUH - } 262 \\
\text { babies } \\
142 \text { males } \\
\text { UWWC - } 62 \\
\text { babies } \\
31 \text { males }\end{array}$ & $\begin{array}{l}\text { Age (hours) } \\
\text { UUH - } 3 \text { to } 96 \text { (mean } \\
26, \text { SD 13.9) } \\
3311 \text { g (SD 434) } \\
\text { UWMC - } 19 \text { to } 102 \\
\text { (mean 40.6, SD 16.9) } \\
3227 \text { g (SD 541) }\end{array}$ & $\begin{array}{l}\text { MEPA } \\
\text { Mimosa } \\
\text { Acoustics }\end{array}$ & $\begin{array}{l}\text { Chirp } \\
\text { Tone }\end{array}$ & $\begin{array}{l}\text { DPOAE, } \\
\text { tympanometry }\end{array}$ & $\begin{array}{l}\text { Referrals in OAE-based infant } \\
\text { hearing screening were } \\
\text { strongly associated with } \\
\text { increased WB reflectance. } \\
\text { Reflectance improved over } \\
\text { the first } 4 \text { days after birth } \\
\text { with normalization of middle- } \\
\text { ear function. Newborns } \\
\text { with normal reflectance and } \\
\text { a refer result for the OAE } \\
\text { screen should be referred } \\
\text { immediately to an audiologist } \\
\text { for diagnostic testing with } \\
\text { threshold ABR due to higher } \\
\text { risk for permanent hearing } \\
\text { loss. }\end{array}$ \\
\hline $\begin{array}{l}\text { Silva } \\
\text { et al., } \\
2013\end{array}$ & 8 & $\begin{array}{l}77 \text { infants } \\
\text { ( } 37 \text { girls and } \\
40 \text { boys) }\end{array}$ & $\begin{array}{l}\text { Age } 27-78 \text { h (mean } \\
56.5 \text { h, SD } 11.6 \text { h) }\end{array}$ & $\begin{array}{l}\text { MEPA - } \\
\text { version } 3.3 \\
\text { Mimosa } \\
\text { Acoustics }\end{array}$ & & $\begin{array}{l}\text { TEOAE, } \\
\text { tympanometry } \\
(226 \text { and } 1000 \\
\text { Hz), acoustic } \\
\text { reflectance }\end{array}$ & $\begin{array}{l}\text { Normal energy reflectance } \\
\text { values were obtained for the } \\
\text { studied population. The data } \\
\text { indicate a reflectance curve } \\
\text { with a distinct configuration } \\
\text { for the studied population. }\end{array}$ \\
\hline $\begin{array}{l}\text { Santos } \\
\text { et al., } \\
2015\end{array}$ & 9 & $\begin{array}{l}31 \text { infant } \\
\text { ears }\end{array}$ & $\begin{array}{l}\text { Age } 10 \text { days to } 5 \\
\text { months }\end{array}$ & $\begin{array}{l}\text { MEPA - version } \\
5.0 \text { Mimosa } \\
\text { Acoustics }\end{array}$ & $\begin{array}{l}\text { Chirp } \\
\text { Tone }\end{array}$ & $\begin{array}{l}\text { HFT } \\
\text { TEOAE }\end{array}$ & $\begin{array}{l}\text { A typical behavior of the } \\
\text { measures, characterized } \\
\text { by a higher reflectance at } \\
\text { low frequencies and higher } \\
\text { absorbance at medium } \\
\text { frequencies was observed in } \\
\text { the population studied. }\end{array}$ \\
\hline
\end{tabular}

Measurement of absorbance involves ascertaining the amount of energy that enters the ear canal, passes through the tympanic membrane, and reaches the middle ear. In contrast, reflectance is a measure of the amount of power that is reflected by the tympanic membrane. Both measures need to be standardized for a newborn population. The bones and cartilage making up the ear canal of neonates is less rigid than in adults. The result is that high frequency acoustic measurements are less affected by the ear canal and better acoustic reflectance and mechanical tympanic membrane and the middle ear $[23,24]$.

Studies on absorbance show great variability in the collected data. Only three studies described the sample being studied in detail. One study evaluated 192 neonates (average age $43.7 \mathrm{~h}$, mean gestational age 39.2 weeks, mean birth weight $3476.9 \mathrm{~g}$ ) [24]. In another study 66 infants, mean age $46 \mathrm{~h}$, were examined [25]. A third study evaluated 32 Aboriginal neonates (mean age $51.9 \mathrm{~h}$ ) and 158 Caucasian neonates (mean age $42.4 \mathrm{~h}$ ) [26]. The other reported studies used sample sizes ranging from 35 to 455 newborn infants' ears. The difference in the presentation of data makes it difficult to compare results, since wideband immittance is affected by the age of the neonate. Again, assessments made close to the time of birth can be influenced by the presence of fluid in the external auditory meatus $[23,27]$.

Significant modifications in wideband absorbance occur during the first 6 months of life because of changes in the external and middle ear. In the first month of life, immaturity means lower absorbance at low frequencies and a significant increase at high frequencies. After this period, the values seem be equivalent to the responses of adults. Another commonly observed feature is the presence of multiple peaks around 0-2 months, while around 4-6 months a single peak is found. Given these differences it is essential that normative studies are developed for different age groups, especially for infants of 0-6 months. A related measure that should be considered is gestational age [23,27].

Studies of wideband reflectance have observed that in neonates there is high reflectance at low frequencies and lower values at $6000 \mathrm{~Hz}$. In contrast, in the adult population there is a low reflectance at $4000 \mathrm{~Hz}$ and an increase at $6000 \mathrm{~Hz}$, a difference which can be explained by size of the ear canal [20-22].

The studies selected here were confined to articles that only used wideband stimuli to assess the middle ear. Studies of reflectance used a chirp or a pure tone, while studies evaluating absorbance used a click. There are no studies in the literature comparing the difference between chirps and clicks. It has been found, however, that in noisy environments results with pure tones are better [20].

\section{Conclusions}

This systematic review observed that wideband immittance is a promising way for evaluating middle ear function in neonates. WBT should be included in newborn hearing screening as it is a fast and objective procedure. This paper highlights the need to establish regulatory standards for different age groups of neonates and infants. 


\section{Funding}

This study was funded by Coordination for the Improvement of Higher Education (CAPES).

\section{Conflicts of interest}

The authors declare no conflicts of interest.

\section{References:}

1. Northern J, Downs M. Audicao na infancia. Rio de Janeiro: Ed. Guanabara Koogan; 2007 [in Portuguese].

2. Yoshinaga-Itano C. Principles and guidelines for early intervention after confirmation that a child is deaf or hard of hearing. J Deaf Stud Deaf Educ, 2014; 19(2): 143-75.

3. American Academy of Pediatrics Joint Committee on Infant Hearing. Year 2007 position statement: Principles and guidelines for early hearing detection and intervention programs. Pediatrics, 2007; 120(4): 898-921.

4. Colella-Santos MF, Diniz Hein TA, de Souza GL, Ramos do Amaral MI, Casali RL. Newborn hearing screening and early diagnostic in the NICU. Biomed Research International, 2014.

5. Collela-Santos MF, de Souza GL, Diniz TA. Triagem auditiva neonatal em UTI. In: Boechat EM, Menezes PdL, Couto CMd, Frizzo ACF, Scharlach RC, Anastasio ART, editors. Tratado de Audiologia, $2^{\text {nd }}$ ed, Rio de Janeiro: Guanabara Koogan; 2015; 386-94 [in Portuguese]

6. Keefe DH, Folsom RC, Gorga MP, Vohr BR, Bulen JC, Norton SJ. Identification of neonatal hearing impairment: Ear-canal measurements of acoustic admittance and reflectance in neonates. Ear Hear, 2000; 21(5): 443-61.

7. Baldwin M. Choice of probe tone and classification of trace patterns in tympanometry undertaken in early infancy. Int J Audiol, 2006; 45(7): 417-27.

8. Jaisinghani VJ, Paparella MM, Schachern PA, Schneider DS, Le CT. Residual mesenchyme persisting into adulthood. Am J Otolaryngol, 1999; 20(6): 363-70.

9. Miura T, Suzuki C, Otani I, Omori K. [Marrow-tympanum connections in fetuses and infants]. Nihon Jibiinkoka Gakkai Kaiho, 2008; 111(1): 14-20 [in Japanese].

10. Hunter LL, Margolis RH. Multifrequency tympanometry: Current clinical application. Am J Audiol, 1992; 1(3): 33-43.

11. Alaerts J, Luts $\mathrm{H}$, Wouters J. Evaluation of middle ear function in young children: Clinical guidelines for the use of 226- and 1,000-Hz tympanometry. Otol Neurotol, 2007; 28(6): 727-32.

12. Tazinazzio TG, Diniz TA, Marba STM, Colella-Santos MF. Emissoes otoacusticas e medidas de imitancia accstica com tons de sonda de 226 e $1000 \mathrm{~Hz}$ em lactentes. Rev CEFAC. 2011; 479-88 [in Portuguese].

13. Sanford CA, Keefe DH, Liu YW, Fitzpatrick D, McCreery RW, Lewis DE et al. Sound-conduction effects on distortion-product otoacoustic emission screening outcomes in newborn infants: test performance of wideband acoustic transfer functions and 1-kHz tympanometry. Ear Hear, 2009; 30(6): 635-52.
14. Keefe DH, Zhao F, Neely ST, Gorga MP, Vohr BR. Ear-canal acoustic admittance and reflectance effects in human neonates. I. Predictions of otoacoustic emission and auditory brainstem responses. J Acoust Soc Am, 2003; 113(1): 389-406.

15. Piskorski P, Keefe DH, Simmons JL, Gorga MP. Prediction of conductive hearing loss based on acoustic ear-canal response using a multivariate clinical decision theory. J Acoust Soc Am, 1999; 105(3): 1749-64.

16. Keefe DH, Levi E. Maturation of the middle and external ears: Acoustic power-based responses and reflectance tympanometry. Ear Hear, 1996; 17(5): 361-73.

17. Feeney MP, Grant IL, Marryott LP. Wideband energy reflectance measurements in adults with middle-ear disorders. J Speech Lang Hear Res, 2003; 46(4): 901-11.

18. Allen JB, Jeng PS, Levitt H. Evaluation of human middle ear function via an acoustic power assessment. J Rehabil Res Dev, 2005; 42(4 Suppl. 2): 63-78.

19. Voss SE, Allen JB. Measurement of acoustic impedance and reflectance in the human ear canal. J Acoust Soc Am, 1994; 95(1): 372-84.

20. Silva KA, Urosas JG, Sanches SG, Carvallo RM. Wideband reflectance in newborns with present transient-evoked otoacoustic emissions. Codas, 2013; 25(1): 29-33.

21. Santos PPd, Araujo ES, Costa Filho OA, Piza MdT, Alvarenga KdF. Wideband acoustic immittance measures using chirp and pure tone stimuli in infants with middle ear integrity. Audiology - Communication Research, 2015; 20(4): 300-4.

22. Hunter LL, Feeney MP, Lapsley Miller JA, Jeng PS, Bohning S. Wideband reflectance in newborns: Normative regions and relationship to hearing-screening results. Ear Hear, 2010; 31(5): 599-610.

23. Hunter LL, Keefe DH, Feeney MP, Fitzpatrick DF, Lin L. Longitudinal development of wideband reflectance tympanometry in normal and at-risk infants. Hear Res, 2015; 340: 3-14.

24. Aithal S, Kei J, Driscoll C, Khan A, Swanston A. Wideband absorbance outcomes in newborns: A comparison with highfrequency tympanometry, automated brainstem response, and transient evoked and distortion product otoacoustic emissions. Ear Hear, 2015; 36(5): e237-50.

25. Aithal S, Kei J, Driscoll C, Khan A. Normative wideband reflectance measures in healthy neonates. Int J Pediatr Otorhinolaryngol, 2013; 77(1): 29-35.

26. Aithal S, Kei J, Driscoll C. Wideband absorbance in Australian Aboriginal and Caucasian neonates. J Am Acad Audiol, 2014; 25(5): 482-94.

27. Aithal S, Kei J, Driscoll C. Wideband absorbance in young infants ( $0-6$ months): a cross-sectional study. J Am Acad Audiol, 2014; 25(5): 471-81. 